Article

\title{
Lullaby: Births, Deaths and Narratives of Hope
}

\author{
Rebekah Pryor
}

Faculty of Arts, The University of Melbourne, Melbourne 3010, Australia; rebekah.pryor@unimelb.edu.au

Received: 2 March 2020; Accepted: 16 March 2020; Published: 18 March 2020

\begin{abstract}
Guided by the hopeful possibilities of birth, breath and beginning that Hannah Arendt and Luce Irigaray variously articulate, this paper examines the lullaby as an expressive form that emerges (in a variety of contexts as distinct as medieval Christendom and contemporary art) as narrative between natality and mortality. With narrative understood as praxis according to Arendt's schema, and articulated in what Irigaray might designate as an interval between two different sexuate subjects, the lullaby (and the voice that sings it) is found to be a telling of what it is to be human, and a hopeful reminder of our capacity both for self-affection and -preservation, and for meeting and nurturing others in their difference.
\end{abstract}

Keywords: Arendt; narrative; natality; Irigaray; difference; interval; lullaby; contemporary art; hope

\section{Introduction}

There is, in the gap between birth and death, a story to be told (or sung).

According to Hannah Arendt, our articulation and sharing of narrative about this interval of time constitutes our humanness and differentiates us from other forms of life. Distinct from goods made, valued and exchanged for our consumption and physical survival, narratives are intangible "'products' of action and speech" that exist and express life for us only in the context of other human life (Arendt 1958, p. 95). Indeed, without "human plurality"—human life in common-, action, speech and even thought are futile activities (p. 95). Evoking Aristotle, Arendt goes further to emphasize the political nature of narrative: the praxis of narrative, where praxis is understood as action-that most agential and potentially destabilizing political gesture-necessarily couched between other elementary activities of living, namely philosophy (theoria) and creativity (poiesis).

Contemporary art practice constitutes one such praxical mode of inquiry and expression. My own creative practice is concerned with alternate ways of imagining the body (particularly the maternal body) in relation, and, in terms of Arendt's proposition, considers the problem of representing maternal experience in its range and entirety; in all its joys and sorrows. ${ }^{1}$ Pushing beyond genealogies and inheritances of the mother in Western Christian art (by which she has too long been cast as quiet, empty vessel, brimming with life only by relation to Father and Son), I wanted to render the maternal body as one with agency, already in the habit of productive action but also capable of speech. A subject in relation with herself and others, capable of articulating her own narrative through speech. An irreducible subject, capable of giving birth to herself, as Luce Irigaray might say. But how to conceive of the gap in which her story is expressed and encountered? Spoken and heard?

Spurred by the new possibilities that Arendt's narrative points us to, this paper hones in on the genre of the lullaby, understood as an expressive, narrative form that sits between natality and

1 This paper draws on my creative, practice-led doctoral research, titled This Is My Body: Re-imagining the mother and the sacred in art and ordinary life, and completed at The University of Melbourne, Australia in 2017. (Pryor 2017) The thesis may be viewed at the University's online repository: http://hdl.handle.net/11343/197462. Artwork from my continuing art practice may be viewed at my website: www.rebekahpryor.com. 
mortality and, via the voice of the mother, bears both in its song. With reference to the lullaby's etymology and occurrence in late medieval Christendom and ordinary life, I consider the significance of the singing voice in contemporary art (including my own) and, ultimately, in helping us to begin (and begin again) to speak, listen and think about hope.

\section{Lullaby}

Cycling between expressions of comfort, lament and joyful hope, lullabies have long expressed sounds and stories of the human condition. Etymologically, the word lullaby is derived from the word lull, meaning "to soothe to sleep or quiescence" (itself a derivation of "lu lu" or "lully, lulla, lullay", sounds commonly sung to a child as they go to sleep), and "by" or "bye-bye" (another colloquial song sound) (Hoad 2003). Even before lyrics form, this sonic quality (by which sung vocal sounds are given and received as waves and vibrations) conveys and attends to the cyclical nature of life itself. The sound of the voice alone may thus be said to constitute a "product" (in that Arendtian sense) of the action of relation across and between human generations.

Lullabies are widespread, and though many of the earliest forms have been lost, accounts of their use and role in domestic settings can be traced back to at least Greek antiquity. According to Giulio Colesanti, scholar in Greek, Italian and Latin literature, ancient Greek lullabies are part of a large volume of "submerged" texts, that is, texts that were either neglected in their transmission, or not transmitted (Colesanti 2014, p. 99). Surviving texts of sixteenth century Greek lullabies (called $v \alpha v o v \rho i \sigma \mu \alpha \tau \alpha$ or nanourismata) help to locate them as songs sung by women (in many cases, illiterate) to infants and children, and performed privately in the familial settings of the home (p. 104). Colesanti contends that, while the authorship of lullabies has also been submerged (this the result of their often anonymous status and the related absence of textual records, as well as the tendency among women to avoid appropriating another household's lyric or composition), lullabies themselves must be considered "as an extreme, quasi paradoxical instance of submersion", given their persistence through time and across cultures (p. 106). They survive as a direct consequence of their performative and adaptable oral form. In the lullaby's most primary sonic form, this adaptability amounts to a kind of intangibility that nevertheless remains affective in its relational context; the sound of the lullaby lulls, even in the absence of words. The further action that fills the singing voice with speech produces a narrative and a different, though equally affective, kind of lullaby. Surviving cradle songs and Christian carols are good examples of this fusion of the acts of lulling and being lulled and of speaking and being spoken to. For late medieval Christian communities in the midst of social crisis and religious reform, this attention to both sound and lyrics propelled the development of particular doctrinal and theological narratives of suffering and salvation.

\section{Cradle Songs and Carols}

Lullabies, or cradle songs, are self-reflexive in character; while their themes and expressions concern the child, they are also "about the act of singing" (Palti 2011, p. 360). By simple definition, they are:

... lyrics with clear internal textual signatures, either the depiction of a scene in which a singer soothes a baby or the presence of lulling words. (p. 361)

As a "participatory lyric tradition" that emerges from a fusion of "literary and musical culture, Latin and vernacular texts, and the scholarly and popular", lullabies are identified as such by the wider socio-historical context of their performance (p. 361). For example, while some lullabies refer to an anonymous child, and many other later medieval cradle songs explicitly reference the Christian nativity story (and specifically, the Mary-Jesus relation), in each case they often also include references to a range of other texts and sources relevant to the contemporary performer or audience. Kathleen 
Palti cites the fourteenth century Lollai, lollai, referred to as the Harley lullaby, as the earliest Middle English example. ${ }^{2}$ Its first stanza reads:

Lollai, $1<$ ollai $>$, litel child, whi wepistou so sore?

nedis mostou wepe, hit i3arkid ${ }^{\circ}$ pe 3ore

Euer to lib $^{\circ}$ in sorrow, and sich ${ }^{\circ}$ and mourne euere,

As pin eldren did we pis, whil hi aliues were.

Lollai, <lollai >, litel child, child lolai, lullow,

In-to vncup world icommen so ertow! (p. 361) $)^{3}$

The Middle English verse can be translated in the following way:

Lollai, lollai, little child, why do you weep so bitterly?

Necessarily you must weep, it was prepared long ago for you

Ever to live in sorrow, and sigh and ever mourn,

As your elders did before this, while they were alive.

Lollai, Lollai, little child, child lollai, lullow,

Into an unknown world so you have come. (Rogers 2008, p. 96)

Despite its child-subject's anonymity, the song's allusions to biblical imagery (particularly in later verses which refer to the fox and bird imagery of Matthew and Luke's gospels (see Palti 2011, p. 362)) demonstrate the intertextual quality of lullabies. Beyond their original cradle-side setting, lullabies became songs complex and robust enough to traverse private and public domains, the latter in performance contexts and Christian religious settings. Thus, the lullaby form is one of "extensive textual mobility", a characteristic that enabled its widespread use, particularly in the form of the carol (p. 365).

The melancholic themes of trauma and lament in Lollai, lollai are not uncommon in the lullaby genre. Life in medieval England was difficult and the death of young children was expected: mothers sang cradle songs "not of magical kingdoms, but of life's struggles and inevitable death" (Hanawalt 1993, p. 62). In this context, the link between the suffering of ordinary mothers and that of Mary-Mother of God and Mother of Sorrows-is not difficult to make. The lullaby genre was thus appropriated by medieval Christian clerics to inspire imitation of Mary and devotion to Christ. Literary historian Amy Vines elaborates on how this identification worked. She states:

Unlike other affective devotional texts, which celebrate the joy inherent in Christ's birth, these lullaby lyrics, I suggest, transform the emotional intimacy of the first interactions between mother and child into a lesson in parental mourning. Mary's shift from lullaby to lament in many of the Nativity lyrics models the emotional shift that is intended to take place within the reader. Picturing a familiar, loving scene with their own children enables the readers to identify more readily with Mary's loss and to understand her sacrifice more fully. (Vines 2010, p. 202)

2 The lullaby, "Lollai, lollai", appears in the parchment codex of 'The Kildare Lyrics' (MS. Harley 913, F. 32R-V), which was once owned by two earls of Oxford, Robert Harley and Edward Harley, and is now held in the collections of the British Library, London. British Library, "Catalogue of Illuminated Manuscripts: Detailed Record for Harley 913", http://www.bl.uk/catalogues/illuminatedmanuscripts/record.asp?MSID=18695\&CollID=8\&NStart=913.

3 In her presentation of a transcription of the Harley MS 913 lullaby (held in the British Library), Palti references the text Religious Lyrics of the XIVth Century, ed. Carleton Brown (Oxford: Clarendon Press, 1924). 
Thus, "powerfully didactic in its simultaneous expression of parental love and loss", through the lens of The Nativity image, the ordinary, private, lyrical moment of soothing between mother and child is disrupted and changed, as Vines suggests, into a call to "a devout Christian life" (p. 223). And so, the carol lullaby was born.

Still retaining the paradox of lulling and lamenting that so characterises the genre, the fifteenth century Coventry Carol is one example of lullaby put to work in service of Christendom's goal of fostering devotion. Created by an unknown author and first recorded as text by Robert Croo in 1534, the lyrics are part of The Pageant of the Shearmen and Tailors, a cycle of mystery plays performed in Coventry, England. Its extant original tune was first discovered and published by Thomas Sharp in 1825. The lyrics read:

Lully, lulla, thou little tiny child,

$B y$, by, lully, lullay.

1. O sisters too,

How may we do

For to preserve this day

This poor youngling,

For whom we do sing,

By by, lully lullay?

2. Herod, the king,

In his raging,

Chargèd he hath this day

His men of might,

In his own sight,

All young childrén to slay.

3. That woe is me,

Poor child for thee!

And ever morn and day,

For they parting

Neither say nor sing

By by, lully lullay! (Dearmer et al. 1928, pp. 44-47)

The carol begins with the lulling sounds typical of the cradle song. In the opening refrain, the singer addresses an unnamed child-assumed to be Jesus, given the gospel allusions that follow-and proceeds to sing to her "sisters" in what is reminiscent of a performance of lament by the weeping women described by Old Testament prophet Jeremiah (Jer 9:1, pp. 17-18). With her first verse, the singer gathers the women (especially other mothers of young children in and around Bethlehem), appealing to them to collaborate in an act of preservation and resistance against an imminent threat to the life of her child and others. "How may we do for to preserve this day ... ?" she cries. The next verse describes the raging king Herod and "his men of might", closely referencing the account of The Massacre of the Infants in Matthew 2:16-18. While the biblical text does not specify that Herod had witnessed the slaughter as the lyrics suggest-it was not uncommon for writers of such carols to incorporate folklore "to fill gaps" left by the gospel authors (Ramalingam 2006)—it does refer to words of Jeremiah who foretold the "wailing and loud lamentation" of another mother, Rachel, who was equally grief-stricken. ${ }^{4}$ The pleading and protest against the tragedy that the Coventry Carol expresses is 
punctuated by the comforting words of the refrain. The final verse expresses the singer's acquiescence: death will come upon her child and she will both resist it and remain inconsolable in her grief. This is Mary's song; the song of a maternal body; the song of a maternal voice. The tone of triumphant praise that characterises Mary's first song, the Magnificat, is long forgotten here and, in the context of the Christmas pageant in which the carol was sung, this served as a potent reminder to the gathered audience that in The Nativity, just as in their own experience, death was imminent and devotion to God was necessary.

Lullay, My Liking is another fifteenth century carol lullaby that presents a narrative account of The Nativity scene. Mary lulls her Christ child with a song, and angels appear, singing and speaking words of blessing and affirmation of the child who is "eternal lord".

Lullay my liking, my dear son, my sweeting;

Lullay my dear heart, mine own dear darling!

1. I saw a fair maiden

Sitten and sing:

She lullèd a little child,

A sweetè lording:

Lullay my liking, my dear son, my sweeting;

Lullay my dear heart, mine own dear darling!

2. That eternal lord is he

That made allè thing;

Of allè lordès he is Lord,

Of allè kingès king:

3. There was mickle melody

At that childès birth:

Although they were in heaven's bliss

They madè mickle mirth:

4. Angels bright they sang that night

And saiden to that child

'Blessed be thou, and so be she

That is both meek and mild':

5. Pray we now to that child,

And to his mother dear,

God grant them all his blessing

That now maken cheer: (Dearmer et al. 1928, pp. 396-99)

In stark contrast to the Coventry Carol, this carol evokes feelings of joy and love, such as that exhibited by the intimate mother-child relation it describes. Again, although the subjects are not explicitly named, the titles bestowed on the child and the biblical reference to angels attending his birth (from Luke 2:13-14) denote its classification as a carol lullaby about Mary and Jesus. As such, its lyrics announce Christ's Incarnation and encourage the faithful audience or congregation of singers to anticipate the presence and cheerful blessings of God in their own lives.

As these examples suggest, the carol lullaby typically progresses in cycles of maternal comfort and lament or joyful hope. While the verses contextualise the mother-child relation, opening space for the listener to reflect on and identify with the lives and perspectives of the songs' central figures (in the case of the Coventry Carol, with Mary the mother who suffers with her suffering son; in Lullay, 
My Liking, with Mary the mother who is devoted to him in love, and Christ who is the God who "made allè thing"), the refrain returns the listener to the iconic site of origin, to the maternal hold: in the first carol, this is a space of respite from sorrow; in the second, it is a space of adoration and hope.

\section{Hope and Natality}

Beginning it all and disrupting what might otherwise be construed as an endless cycle of growth and decay (paralleled in common life to a cycle of production and consumption in which human life itself becomes "superfluous" or extra to the totalizing imperial systems that drive it (see Arendt 1951)), the event of our birth enables our capacity and initiative for action and newness (and, given our humanness, storytelling) thereafter. For Arendt, birth, framed in divine terms as miraculous, thus conjures hope:

The miracle that saves the world, the realm of human affairs, from its normal, "natural" ruin is ultimately the fact of natality, in which the faculty of action is ontologically rooted. It is, in other words, the birth of new men and the new beginning, the action they are capable of by virtue of being born. Only the full experience of this capacity can bestow upon human affairs faith and hope... (p. 247)

Recognising the facts of love and relation, by which this natality comes to be, further helps us realise its potential. Luce Irigaray, who similarly returns us to the hopeful possibilities that come from the event of our birth, writes, "We are the ec-stasis from a union, the unpredictable advent of a not appropriable event" (Irigaray 2017, p. vi). Undoing the myth of continuity that a nostalgic preoccupation with genealogy orients us to, and restating her original thesis of sexuate belonging (which "allows for a gathering with and within oneself but also for relating to and with the other(s)"), Irigaray urges a return to our ecstatic beginning, when, even given the unpredictability of the union from which we came to be, we breathed on our own - we gave birth to ourselves (5). The little human's action of autonomous breathing and sexuate belonging are what enable it to cultivate life for itself in relation to others. Giving birth to oneself then, through the first and every breath thereafter, lets us realise our capacity as "a life irreducible to any other" (5). Being born is, as Arendt also implies, a most political and, thus, precarious action.

Irigaray is careful not to forget the mother-more precisely, the woman in the mother-from whose body we emerged. Indeed, the mother is the first with whom we are in relation, even if, at the start, she appeared to us as transcendent, in that vertical sense, as "a 'You' rather than a 'you'" (Irigaray 2008, p. 120). Irigaray's point is that we inherit the world-more accurately, $a$ world-of and through that first relation and, while we may accept or rebel against it, if we fail to recognise the mother as subject, we risk confusing her with the world we make as her substitute and making them both objects reduced as such for our service and consumption. On this trajectory, we position ourselves far from the intangible, relational, hopeful, story-ful, ever new world that Arendt characterises as distinctly human life. In this context, where discourse is "determined by a world that already exists: it does not arise from the relation with the other as such", speech itself risks repeating only that which has already been prescribed in the world as it appears (Irigaray 2008, p. 125).

Arendt and Irigaray both acknowledge the cyclical nature of life (even beyond the human) and variously highlight the opportunities that the advent of a new life opens up: Arendt via the language of natality, and Irigaray via ecstasis. Each identifies the uniqueness of the new life and the possibilities, beyond the one, that such a new beginning allows. ${ }^{5}$ This gaping ontology returns us to "bodily existence", as Grace Jantzen asserts; to beginnings "always material, embodied ... "

5 In outlining her theology of creatio ex profundis (by which, put simply, all things emerge from a divine, deep, endlessly multiple capacity rather than a vast nothingness), theologian Catherine Keller wonders: "What if beginning-this beginning, any beginning, The Beginning—-does not lie back, like an origin, but rather opens out? "To begin" derives from the old Teutonic be-ginnan, "to cut open, to open up", cognate with the Old English ginan, meaning "to gape, to yawn", as a mouth or 
(Jantzen 1999, p. 145). In turn, it also opens us up to questions of ethics (and relatedly, action and speech) about how newness, difference and their innumerable possibilities are encountered and perceived in common life (which is also to say, life in common).

\section{The Singing Voice as "Materiality of the Body" in Relation}

In life's natural cycles of growth and decay, between birth and death, narratives both articulate our humanness and call us to notice the humanness of others. The lullaby cycle, in which sounds of comfort punctuate ordinary experiences of parental love and lament, effectively attends to this matter of ethics. It also resonated with my experience as a mother of infants and young children and, in time, became a focus of my visual art practice. Continuous Narrative (2015) even came to incorporate the Lullay, My Liking refrain, in an attempt to locate, express and examine the maternal rhythms I had experienced:

eat play sleep eat play sleep eat play sleep eat play sleep eat play eat play eat play sleep wake scream eat play sleep eat play sleep cry cry cry wake me up eat play sleep eat play sleep eat play sleep in my arms heavy dead eat play sleep shh sleep sleep lullay mine liking my dear son mine sweeting lullay my dear heart mine own dear darling you sleep all night eat play sleep eat play smile at me make me cry sleep eat play sleep sleep sleep long sleep today lucky me eat play sleep eat play sleep eat play sleep eat play sleep day after day eat play sleep chatter eat play sleep eat play sleep eat play sleep crawling now eat play sleep eat play sleep eat play sleep laugh and chatter and crawl and wail eat play sleep wake in dark of night eat sleep rouse me from good sleep obedient instinct eat play eat again ceaseless chatter sleep eat play totter teeter sleep sleep afternoon sleep me too eat play sleep show us make us smile eat play sleep same stuff as yesterday less sleep more chatter eat play sleep wake cry no eating today just crying medicate your hot body lullay my dear heart mine own dear darling you sleep I watch listen to you breathe sleep eat play sleep eat play chatter tell you all the things I know all the things sleep sleep sleep sleep eat play sleep eat play sleep eat play sleep eat play walk like you've always done it tire sleep sleep eat play sleep eat play sleep eat play walk run trip bleed scream with no sound I weep Jesus wept I hold hold hold you sleep eat play sleep eat play play play fall in a heap sleep dream of hens gathering chicks under wings (Pryor 2015)

In this text work-written in table salt across the entire $5.7 \times 7.5 \mathrm{~m}$ floor of the gallery room-I aimed to express the cyclical experience of the maternal body in relation with her child. While I had done so in my own words and, at times, in the Middle English lyrics of others, it seemed (at least to me) to lack a mystery or mobility that sung lullabies exhibit. Thus, I turned to the medium of the voice.

Constituting a certain depth and condition of "betweenness"- -between "expression, transmission, and storage" (Bruno 2014, p. 5) —-the singing voice is itself "materiality of the body", as philosopher Roland Barthes describes:

The singing voice, that very specific space in which a tongue encounters a voice and permits those who know how to listen to it to hear what we call its "grain" - the singing voice is not the breath but indeed that materiality of the body emerging from the throat, a site where the phonic metal hardens and takes shape. (Barthes 1985, p. 255)

Sung in the voice of a mother (or other) to a child who knows how to hear it, the lullaby is thus intersubjective. It is comprised of at least two subjects and sounds the relation between them. The "grain" of the singing voice operates in what we may here designate as an interval, allied to Arendt's "time interval between birth and death" (Arendt 1958, p. 97) and Irigaray's interval of the

an abyss." (Keller 2003, p. xv) For Keller, a further, critical question follows and provokes a turn to ethics: “Do we-religious or irreligious-just gape a moment, yawn and look away?" (pp. xv-xvi). 
"sensible transcendental" between two sexuate (and so, irreducible) human subjects (Irigaray 1993, p. 129). Bearing the hopeful, as-yet-unimagined capacity of all and any "beginning" (Keller 2003, p. xv), and active in what Barthes describes as "a double posture, a double production", "the body in the singing voice" produces both sound and speech that, in the relational context of the interval, is entirely political (Barthes 1985, p. 269). The singing voice operates between the singer and the listener, not in a unidirectional mode by which the ear of the listener works to decipher particular meanings emitted by the singer; rather, the singing voice demands a multiple and intersubjective kind of listening in which, as Barthes explains, "I am listening' also means 'listen to me'" (p. 269). In this sense, the singing voice asks for the kind of ethical relation that Arendt's vital narrative and Irigaray's sexuate belonging demand; the sound of the song reverberates in such a manner as to ensure that both subjects are able to identify themselves through their own difference, while simultaneously enabling the other to do the same. No subject is summarised or curtailed inside such a relation; the voice, as a remainder, proves it.

The human voice is, as a matter of fact, the privileged (eidetic) site of difference: a site which escapes all science, for there is no science (physiology, history, aesthetics, psychoanalysis) which exhausts the voice: no matter how much you classify and comment on music historically, sociologically, aesthetically, technically, there will always be a remainder, a supplement, a lapse, something non-spoken which designates itself: the voice. (p. 279)

For Palestinian filmmaker Nurith Aviv, this is "the secret of the voice" (Aviv 2013). In her 2013 film, Annonces (Announcements), Aviv gathers a range of women to consider the effects of thought, language, voice and image through the theme of announcement, specifically the announcements to Hagar, Sarah and Mary as they occur in the Bible and Koran. Professor Ruth HaCohen (Pinczower) in particular emphasises the nexus between divine announcement and the singing voice (or, in the Old Testament case of Sarah, the melodic laughing voice). In Hagar's cry, Sarah's laugh and Mary's song, the voice materialises an uncontainable overflow (of difference, mystery and joy). ${ }^{6}$ Other films by Aviv, including her trilogy Misafa Lesafa (From Language to Language) (2004), Langue Sacrée, Langue Parlée (Sacred Language, Spoken Language) (2008) and Traduire (Translate) (2011), also emphasise the mobility of vocalised language, and show, as Jacques Mandelbaum states, that "language is both a crucible of meanings and a challenge to purity" (Mandelbaum 2011).

Referencing German composer Robert Schumann for his use of the vernacular from his "mother tongue", Barthes describes this use of language in music as a "declared restoration of the body" that locates the voice and music in the space of the chora (Barthes, p. 310). In order to achieve this, the listening subject must go beyond hearing the alert of rhythm and deciphering a pre-existing order of codes; they must instead listen for the secrets emitted from the intersubjective space of the chora. This is more than a religious activity. It is mystical, and a shift that the lullaby itself promotes: a shift that sees the woman in the mother listening-attending- to herself and discovering not only the infant other to whom she sings, but herself and all others there too.

What is clear then is that the woman in the mother remains capable of nurturing herself only if she persists as a multiple subject. The lullaby conveys the maternal body in light of this possibility, suggesting that, in the act of singing, the mother practices self-affection — the "art of interiority" Irigaray argues is critical to our becoming - and in this way ensures for herself the kind of ecstatic, irreducible life that was hers from the beginning (Irigaray 2008, p. 136; 2017, p. 5). ${ }^{7}$ Irigaray asserts that this is

6 Refer to The Holy Bible's accounts of Hagar's plea (Genesis 16, 21:8-21), Sarah's laugh (Genesis 18:12, 21:6-7) and Mary's song (Luke 1:46-55).

7 Irigaray is hopeful that this capacity is required if we are to share the world: "Self-affection corresponds to an art of interiority, of internalization, that we have to discover, to invent, to cultivate, and to express: in ourselves and between us. Such an art can lead the way towards our becoming universal and convivial beings, capable of coexistence with all differences. This art is thus the mediation necessary for constructing together a shareable world" (Irigaray 2008, p. 136). She continues to insist on this in To Be Born, when she reminds us of each human life's ecstatic beginning and first breath: "Through its autonomous breathing and its sexuation, the little human gives birth to itself, it brings into the world a singular living being of which it 
"a gesture of gathering oneself together, of communing with oneself, which must go with becoming" (p. 17). While this is a practice "extraneous to our Western tradition"-peripheral if not altogether absent from Western culture and religion, particularly in contrast to Eastern contexts-whatever religious or non-religious tradition frames it, our human becoming necessitates the self's gathering and communing. And it is a courageous gesture, as Irigaray says:

Becoming oneself requires as much heroism as being born, and also needs resorting to our breath in order to emerge from the family and sociocultural background which, too often, substitute themselves for the maternal placenta in which we started living. It is a matter of winning an existence of our own again. (p. 42)

It is the kind of gesture that enables a mother to allow experiences of love and lament to reverberate back to her again and again in the bitter-sweet sound of her own voice; in the singing of a lullaby.

\section{Lullaby (2016) and Other Works of Contemporary Art}

Lullaby (2016) was, for me, something of a return to earlier themes of maternal cycles and genealogies. In this short video work (see Pryor 2016), the lullaby, sung in my own voice, is used to locate and materialise the body of the mother. The lyric and melody are those of the nineteenth century Brahms' Lullaby. The sound and moving image of a music box mechanism accompanies the layered vocal arrangement, signalling the mother's animation in relation with her child. With singing voice as body, as Barthes describes, the mother is imagined here as corporeal and symbolic, holding and abiding, arriving and returning; as fragmented and, at times, discordant; as multiple, cyclical and pertaining to her own rhythm; as remainder that audibly and philosophically exceeds the symbolising closure of the image.

A further contemporary art example is that of Australian musician, vocalist and performer Sophia Brous. Her Lullaby Movement (Brous 2017) is a performance incorporating lullabies from Africa, Asia, Europe, the Americas and the Middle East to explore the universality of human need and desire. The performance is framed by the narrative of a girl who sings out lullaby melodies from the edge of the universe in anticipation of a response (that might affirm the existence of another form or being). Brous sings a lullaby song cycle; voice and melody lead the audience through the movement from Nightfall to Midnight, Witching Hour, Deep Night into Day Break. Playing a range of instruments including the guitar, jaw harp, violectra and nose flute, accompanying musicians and fellow-composers Leo Abrahams and David Coulter create depths of sound that variously support, lead, mimic and respond to the singer's wide-ranging vocals. Brous' voice embodies the movement: sometimes it quietly, gracefully lulls or persuades to sleep; at other times, it rapidly traverses scales, pitches and lyrics, mimicking the girl's own cosmic exploration; during the Witching Hour, the voice sings voluminously, in time with the heavy beat of the singer's hand slapped hard against her body, and straining through a grain of voice that implies desperate protest; and still other times, the voice bounces, following a joyful rhythm set by a hand gently clapping the chest. The movement concludes with an Epilogue: Brous sings the Greek Cypriot lullaby, Ayjia Marina (Saint Marina, Misty Maiden), its lyrics (translated) seeking the saint's blessing of slumber on the child, the chest of the mother, the river, birds and seasons (Brous 2014).

While at times the framing narrative seems superfluous to the lullabies' melodic figuring of the maternal body, it does help, not only to keep the artist's quest for unbounded universals in view-the guiding sense of the work is that there is something common to us, shareable in human experience, that transcends the confines of national borders and languages-but also to imply the reflexive nature of the voice that sings for/to the other and discovers itself (by listening) in response.

will have to cultivate life, a life irreducible to any other, towards its achievement for itself and for the world into which it takes place" (Irigaray 2017, p. 5). 
In this sense, the lullaby constitutes a collective and transformative revelation, as Brous herself suggests (Cathcart 2017). However, in its difference across cultures and languages, the lullaby also brings into focus the uniqueness of the voice, and the voice as and in bodies. By definition, as Barthes has already outlined, the voice evades the universal. And so, we are returned again to critical questions of ethics: whose voice sings? whose voice is allowed to sing? and whose is heard? These are not simple questions given each human voice is cultivated in a specific body, and each body exists and functions within a specific cultural context. In combination, these particularities affect the capability of the voice. While I observed Brous' compelling performance, I also wondered what it would be like to have heard the Latvian mother, the Afghani mother, the Serbian mother, the Ugandan mother, and so on, each perform her own song in her own voice.

\section{Conclusions}

Arendt's narrative proposition amplifies the political possibilities for hope in common life. In a world paralysed by cycles of growth and decay, that most hopeful event of new birth, along with the life and stories we produce and share through breath (in ourselves and between us, as Irigaray contends), remind us that we are "specifically human". As this discussion has proposed, the possibilities Arendt anticipates are also contingent on the cultivation and preservation of life in all its multiplicity and difference. Attending to the aesthetic problem of representing the gap between different human subjects and experiences, my explorations in contemporary art suggest that the lullaby itself constitutes an in-between, an interval by which such multiplicity and difference is maintained. Expressed and encountered as sound and lyric - ultimately, as narrative of life and death, joy and lament, salvation and suffering - the lullaby (along with the singing voice that shares it) returns us to our capacity for self-affection and -preservation, and to the loving, hopeful posture of meeting and being met, holding and being held by the different others with whom we are in relation.

And so, in returning to our beginning - to that opening, vast and deep; to birth and breath breathed in, out; to cradle songs voiced from depths of love-we find ourselves also returned to the cycles and lulling rhythms of the everyday: to life ordinary and mysterious; at once familiar and completely new. In Prières Quotidiennes, Irigaray writes:

There are some realities which are to be lived without first knowing what they are or how to approach them. The wise, the mystics, lovers and poets behave in this way. (Irigaray 2004, p. 37)

With her, we pray: "Let us hope they continue to do so ... " (p. 37).

Funding: The doctoral research on which this article draws was funded by the Australian Government Research Training Program, the Australian Postgraduate Award, The University of Melbourne, and the Bishop Perry Institute, The Anglican Diocese of Melbourne.

Conflicts of Interest: The author declares no conflict of interest. The funders had no role in the design of the study; in the collection, analyses, or interpretation of data; in the writing of the manuscript, or in the decision to publish the results.

\section{References}

Arendt, Hannah. 1951. The Origins of Totalitarianism. New York: Harcourt, Brace and Co.

Arendt, Hannah. 1958. The Human Condition. Chicago: The University of Chicago Press.

Aviv, Nurith. 2013. Annonces: Synopsis. Nurith Aviv. Available online: http://nurithaviv.free.fr/annonces/synopsis. htm (accessed on 27 October 2017).

Barthes, Roland. 1985. The Responsibility of Forms: Critical Essays on Music, Art, and Representation. Berkeley: University of California Press.

Brous, Sophia. 2014. Lullaby Movement Lyrics. Urban Theatre Projects. Available online: http://urbantheatre. com.au/wp-content/uploads/2014/10/LULLABY-MOVEMENT_LULLABY-LYRICS.pdf (accessed on 19 August 2017). 
Brous, Sophia. 2017. Lullaby Movement. Melbourne: Arts Centre Melbourne.

Bruno, Giuliana. 2014. Surface: Matters of Aesthetics, Materiality and Media. Chicago: The University of Chicago Press.

Cathcart, Michael. 2017. Interview with Sophia Brous. Lullabies at Supersense Festival of the Ecstatic. Books and Arts Daily; Melbourne: Radio National, August 15. Available online: https://www.abc.net.au/radionational/ programs/archived/booksandarts/lullabies-at-supersense-festival-of-the-ecstatic/8804894 (accessed on 19 August 2017).

Colesanti, Giulio. 2014. Two Cases of Submerged Monodic Lyric: Sympotic Poetry and Lullabies. In Submerged Literature in Ancient Greek Culture: An Introduction. Edited by Giulio Colesanti and Manuela Giordano. Berlin: Walter De Gruyter, pp. 90-106.

Dearmer, Percy, R. Vaughan Williams, and Martin Shaw, eds. 1928. The Oxford Book of Carols. London: Geoffrey Cumberlege and Oxford University Press.

Hanawalt, Barbara. 1993. Growing up in Medieval London: The Experience of Childhood in History. New York: Oxford University Press.

Hoad, F. T., ed. 2003. The Concise Oxford Dictionary of English Etymology. Oxford: Oxford University Press.

Irigaray, Luce. 1993. An Ethics of Sexual Difference. New York: Cornell University Press.

Irigaray, Luce. 2004. Prières Quotidiennes: Everyday Prayers. Paris: Maisonneuve \& Larose.

Irigaray, Luce. 2008. Sharing the World. London: Continuum.

Irigaray, Luce. 2017. To Be Born. Cham: Palgrave Macmillan.

Jantzen, Grace. 1999. Becoming Divine: Towards a Feminist Philosophy of Religion. Bloomington: Indiana University Press.

Keller, Catherine. 2003. Face of the Deep: A Theology of Becoming. Oxon and New York: Routledge.

Mandelbaum, Jacques. 2011. Traduire-Review. The Guardian. Available online: https://www.theguardian.com/ film/2011/feb/01/nurith-aviv-film-language-review (accessed on 19 August 2017).

Palti, Kathleen. 2011. Singing Women: Lullabies and Carols in Medieval England. The Journal of English and Germanic Philology 110: 359-82. [CrossRef]

Pryor, Rebekah. 2015. Continuous Narrative. Rebekah Pryor Artist. Available online: https://www.rebekahpryor. com/salt (accessed on 10 January 2020).

Pryor, Rebekah. 2016. Lullaby. Rebekah Pryor Artist. Available online: https://www.rebekahpryor.com/lullaby (accessed on 10 January 2020).

Pryor, Rebekah. 2017. This Is My Body: Re-Imagining the Mother and the Sacred in Art and Ordinary Life. Ph.D. thesis, The University of Melbourne, Melbourne, Australia.

Ramalingam, Vivian. 2006. Mary, Virgin: In Music. In Women and Gender in Medieval Europe: An Encyclopedia. Edited by Margaret Schaus. New York: Routledge, p. 548.

Rogers, Cynthia Anne. 2008. Singing from the Book: An Analysis of the Middle English and Latin Lullaby Lyrics in Harley 913. Master's thesis, Faculty of the Graduate College, Oklahoma State University, Stillwater, OK, USA.

Vines, Amy N. 2010. Lullaby as Lament: Learning to Mourn in Middle English Nativity Lyrics. In Laments for the Lost in Medieval Literature. Edited by Jane Tolmie and M. J. Toswell. Turnhout: Brepols, pp. 201-23.

(C) 2020 by the author. Licensee MDPI, Basel, Switzerland. This article is an open access article distributed under the terms and conditions of the Creative Commons Attribution (CC BY) license (http://creativecommons.org/licenses/by/4.0/). 